УДК 35.08

\title{
СТАТИСТИЧЕСКИЙ АНАЛИЗ \\ ДОПОЛНИТЕЛЬНОГО ПРОФЕССИОНАЛЬНОГО ОБРАЗОВАНИЯ КАДРОВ ГОСУДАРСТВЕННЫХ ОРГАНОВ
}

\author{
Аверин Александр Николаевич \\ доктор философских наук, профессор \\ Борисова Наталья Сергеевна \\ старший преподаватель \\ Выжигин Александр Юрьевич \\ кандидат технических наук, доцент, заведующий кафедрой \\ Шишков Василий Валерьевич \\ кандидат политических наук, доцент \\ Российская академия народного хозяйства и государственной \\ службы при Президенте Российской Федерации
}

Аннотация: В государственных органах с высшим образованием в 2018 году насчитывалось 725524 (95\%) работника, средним профессиональным 35049 (4,6\%), не имели профессионального образования - 3197 (0,4\%). Второе высшее образование имели 196482 (14,7\%), ученую степень кандидат наук - 9615 (1,3\%), доктора - 731 (0,1\%). [1]. Вместе с тем у работников есть необходимость и возможность получать дополнительное профессиональное образование. Это связано с тем, что в стране и мире в целом происходят кардинальные изменения, оказывающие существенное воздействие на государственное управление. В статье на основе статистических данных анализируется повышение квалификации и профессиональная переподготовка кадров государственных органов.

Ключевые слова: государственный орган, обучение, повышение квалификации, профессиональная переподготовка, работник. 


\title{
STATISTICAL ANALYSIS OF ADDITIONAL VOCATIONAL EDUCATION FOR PUBLIC OFFICIALS
}

\author{
Averin Alexander \\ Borisova Natalia \\ Vyzhigin Alexander \\ Shishkov Vasily
}

\begin{abstract}
In 2018, there were 725,524 (95\%) in government institutions with higher education. 35,049 (4.6\%), 3,197 (0.4\%) had a second vocational education of 196,482 (14.7\%), a PhD candidate 9,615 (1.3\%), and 731 (0.1\%). At the same time, workers have the need and opportunity to receive additional vocational education. This is due to the fact that the country and the world as a whole are undergoing dramatic changes that have a significant impact on public administration. The article analyzes the development of skills and professional retraining of public bodies on the basis of statistics.
\end{abstract}

Key words: state body, training, professional development, professional retraining, employee.

В 2019 году 763770 работников замещали государственные должности и должности гражданской службы в государственных органах. [1]. Получили дополнительное профессиональное образование в 2018 году 197518 человек, что составляет 21,5\% от численности работников. Обучено $2444(17,3 \%)$ работника законодательной власти, 160846 (22,6\%) - исполнительной, 31158 $(17,7 \%)$ - судебной власти и прокуратуры, 2963 (20,6\%) - других государственных органов. [2]. В федеральных государственных органах обучались 128684 работника (19,4\%), из них на федеральном уровне - 10781 (27,6\%), региональном - 117903 (18,8\%). В законодательной власти получили образование 480 (14\%) работников, исполнительной - 103406 (20,1\%), судебной власти и прокуратуре - 24186 (16,9\%), других государственных органах - 505 (33,3\%). В региональных государственных органах обучались 68834 (26,9\%) работника, из них 1964 (18,4\%) - в законодательной власти, 57440 (28,9\%) - исполнительной, 6972 (20,9\%) - судебной, 2458 (19,1\%) других государственных органах.

Представляет несомненный интерес статистический анализ обучения женщин и мужчин. Среди работников государственных органов значительно 


\section{СОВРЕМЕННОЕ СОСТОЯНИЕ И ПЕРСПЕКТИВЫ РАЗВИТИЯ

преобладают женщины - 73,2\% от общей численности работников (559 338 человек). Мужчин насчитывалось 26,8\% (204 432). [1]. В абсолютных цифрах получили образование больше женщин (149 771) по сравнению с мужчинами (56 746). [2] В процентном отношении от численности работников различие между обученными мужчинами и женщинами не очень значительно соответственно 23,3\% и 20,8\%. Следовательно, доля мужчин, получивших образование, в общей численности работников выше доли женщин. В законодательной власти доля прошедших обучения мужчин и женщин составила соответственно 14\% и 19,3\%, исполнительной - 24,1\% и 22\%, судебной власти и прокуратуры - 21\% и 16,9\%, других государственных органах - 19,3\% и 21,2\%. Доля обученных мужчин выше доли женщин в федеральных $(21,2 \%$ и $18,7 \%)$ и $\quad$ региональных $\quad(28,3 \%$ и $26,4 \%)$ государственных органах.

Примерно одинакова доля обученных работников, замещающих государственные должности $(23,8 \%)$ и должности государственной гражданской службы (21,3\%). Существуют различия среди обученных по категориям должностей. Более высокая доля обученных у руководителей $(29,1 \%)$, наиболее низкая - помощников, советников (15,9\%). Доля работников, которые впервые поступили на гражданскую службу, составила $15,2 \%$.

Обучение осуществляется по государственному заказу. Было обучено 92502 человека (10\% от численности работников), в том числе 39910 (6\%) в федеральных государственных органах, из них 5171 (13,2\%) на федеральном и 34739 (5,6\%) региональном уровне, 52592 (20,6\%) - региональных государственных органах. В законодательной власти получили образование 1886 работников (13,4\%), исполнительной - 71656 (10\%), судебной власти и прокуратуры - 17047 (9,7\%), других государственных органах - 1813 (12,6\%). Прошли обучение по государственному заказу $6343 \quad(9,1 \%)$ работников, впервые поступивших на гражданскую службу.

Статистический анализ свидетельствует, что преобладает повышение квалификации. 191777 работников (97,1\% от численности обученных) окончили эти программы. Во многом это связано с нежеланием освобождать сотрудников от работы на продолжительное время в период обучения. Объем часов по повышению квалификации должен быть не менее 16 часов, профессиональной переподготовке - не менее 500 часов. Профессиональную переподготовку прошли 5705 работников (2,9\%). Доля прошедших обучение 


\section{СОВРЕМЕННОЕ СОСТОЯНИЕ И ПЕРСПЕКТИВЫ РАЗВИТИЯ

по этим программам составила в федеральных государственных органах 2,3\%, в том числе на федеральном уровне - 7,2\%, региональном - 1,8\%, государственных органах субъектов Российской Федерации - 4\%. Небольшая доля работников, прошедших профессиональную переподготовку, была в федеральных государственных органах на федеральном уровне в других государственных органах $(0,8 \%)$, наибольшая доля - в органах судебной власти субъектов Российской Федерации (7,8\%). За пределами российской территории обучались всего 36 человек, в том числе 31 в государственных органах субъектов Российской Федерации и 5 в федеральных государственных органах. Повышение квалификации преобладало при получении образования по государственному заказу. 90728 работников (98,1\%) повысили квалификацию и 1767 (1,9\%) - прошли профессиональную переподготовку. Наибольшая доля прошедших профессиональную переподготовку была в органах судебной власти и прокуратуры $(4,1 \%)$, наименьшая доля - в исполнительной власти $(1,4 \%)$. В исполнительной власти доля обученных в федеральных органах составила $0,6 \%$, в том числе на федеральном уровне - 0,3\%, региональном - 0,6\%. Только 66 (1\%) работников, впервые поступивших на гражданскую службу, получили профессиональную переподготовку.

В финансировании образования превалировали средства федерального бюджета. За счет его средств обучено 136038 (66,4\%) человек. Средства бюджета субъекта Российской Федерации были направлены на обучение 66701 работника (32,5\%), в том числе по государственному заказу - 56076 (27,4\%), иных источников - 2256 (1,1\%), из них 1138 (0,6\%) - средства работников. 9 человек обучались за счет финансовых источников международных, иностранных органов и организаций. Средства федерального бюджета преобладают в финансировании образования работников исполнительной власти (65,5\%), судебной власти и прокуратуры $(78,9 \%)$, регионального бюджета - законодательной власти $(77,6 \%)$, иных источников и средства работников - других государственных органов (соответственно $3,5 \%$ и $2,8 \%$ ).

Образование осуществлялось в государственных, муниципальных, частных образовательных организациях. В государственных федеральных учебных заведениях обучены 144217 (70,4\%) работников, субъектов Российской Федерации - 35292 (17,2\%), муниципальных - 309 (0,2\%), частных - 14353 (7\%), других организациях, осуществляющих обучение, - 


\section{СОВРЕМЕННОЕ СОСТОЯНИЕ И ПЕРСПЕКТИВЫ РАЗВИТИЯ

10822 (5,3\%). Процент обученных работников федеральных и региональных государственных органов в этих видах образовательных организаций разный. В федеральных государственных органах получили образование соответственно $87,7 \% ; \quad 4,1 \% ; \quad 0,2 \% ; \quad 4,6 \% ; \quad 3,4 \%$, региональных государственных органах - 38,7\%; 41,1\%; 0,2\%; 11,4\%; 8,7\%. Больше всего доля обученных в государственных федеральных учебных заведений составила у работников органов судебной власти и прокуратуры $(74,7 \%)$, муниципальных - исполнительной власти $(0,2 \%)$. Работники других государственных органов отдали предпочтение образовательным организациям субъектов Российской Федерации (26,6\%), частным (13,9\%), организациям, осуществляющих обучение (12,1\%). Работники федеральных органов государственной власти преимущественно обучались в федеральных учебных заведениях (87,7\%), органов субъектов Российской Федерации - в региональных $(41,1 \%)$. Вместе с тем большая доля работников региональных государственных органов, прошедших обучение в федеральных учебных заведениях, была у работников законодательной $(48,3 \%)$ и судебной $(56,3 \%)$ власти, других государственных органов (37,7\%).

Соответственно 128396 (65\%) и 69122 (35\%) работников обучались с отрывом и без отрыва от государственной гражданской службы. Используется дистанционное обучение - обучено 75025 работников (38\%). Больше всего прошли обучение работники исполнительной власти (45,5\%), меньше всего судебной власти и прокуратуры $(4,2 \%)$. Существует значительный разрыв в использовании дистанционное обучение между федеральными и региональными государственными органами (соответственно 53,1\% и 9,6\% работников).

Следует особо отметить значение Российской академии народного хозяйства и государственной службы при Президенте Российской Федерации, поскольку она занимается подготовкой, профессиональной переподготовкой, повышением квалификации кадров не только для системы государственного управления, чем занимаются другие учебные заведения, но и для формирования и развития кадрового резерва всех уровней. Заслуживает особого внимания программа «Высший резерв управленческих кадров» объемом 500 часов, реализуемая Высшей школой государственного управления - структурного подразделения академии. Программа предназначена для подготовки высшего уровня резерва - руководителей органов государственной власти. Выпускниками Высшей школы 
государственного управления стали 29 губернаторов и глав регионов, 15 руководителей федеральных министерств и ведомств. [3].

Статистические данные свидетельствуют о масштабах обучения работников государственных органов. Вместе с тем необходимо отметить, что 285792 сотрудника (31\% от общей численности работников) не получили дополнительное профессиональное образование за три года. 7495 человек получили такое образование и уволились $(3,8 \%$ от общей численности обученных работников).

Таким образом, на повышение эффективности государственного управления, работы государственных органов существенное влияние оказывают не только статистические количественные данные об получивших дополнительное профессиональное образование, но прежде всего качество этого образования, умение использовать полученные знания в управленческой деятельности.

\section{Список литературы}

1. Состав работников, замещавших государственные (муниципальные) должности и должности государственной гражданской (муниципальной) службы, по полу, возрасту, стажу работы, образованию на 1 октября 2019 года. Том I, II (по Российской Федерации, ветвям власти и уровню управления). Статистический бюллетень. Москва, 2020 // https://rosstat.gov.ru/ compendium.

2. Дополнительное профессиональное образование кадров государственной и муниципальной службы в 2018 году. Том I (по России). Статистический бюллетень. Москва, 2019 // https://rosstat.gov.ru/compendium/ document/13288.

3. Сайт Российской академии народного хозяйства и государственной службы при Президенте Российской Федерации // https://gspm.ranepa.ru/. 